\title{
The Influence of FDI with GDP its Impact of FDI in Civil Aviation Sector in India
}

\author{
A. Muthusamy, G. Kalpana
}

\begin{abstract}
The Civil Aviation Sector in India includes Airports, Scheduled and Non-Scheduled, Domestic Passenger Airlines Helicopter Services, Ground Handling Services, Maintenance and Repair Organizations, Flying Training Institutes and Technical Training Institutions. The government has issued the National Civil Aviation Policy on 2016. The Civil Aviation Sector currently contributes $\$ 72$ billion to Gross Domestic Product. The National Civil Aviation Policy covers the policy areas such as Regional Connectivity, Safety, Air Transport Operation, 5/20 requirement for International Operations, Bilateral Traffic Rights, Fiscal Support, Maintenance, Repair and Overhaul, Air Cargo, Aeronautical 'Make In India'. The Central Government announces that the foreign airlines now will be allowed to invest in domestic airlines up to 49 percent. The researcher has to study the impact of FDI Inflows in Aviation Sector in India and Annual Growth Rate of FDI Inflows in Aviation Sector in India. FDI is necessary for all stakeholders and partners to work together to maximize the benefits of air transport, and to support the sustainable growth of aviation by connecting more people and more places. Aviation has continued to expand. It has weathered crises and confirmed long-term resilience, becoming a crucial means of transport. Historically, air transport has doubled in size every 15 years and has grown earlier than most other industries. The researcher has used Statistical Tools such as, Trend Analysis, Descriptive Analysis, and Regression. The present study covers period of ten years taking from 2009-10 to 2018-19. The research paper concludes the positive growth and positive impact of FDI in Aviation Sector.
\end{abstract}

Keywords : FDI,.

\section{INTRODUCTION}

The role of FDI in the economic growth process has been a burning topic of debate in several countries including India. FDI is a vital component of the globalization efforts of the world economy. The growth of international production is driven by economic and technological forces. It is also driven by the ongoing liberalization of Foreign Direct Investment (FDI) and trade policies. FDI flows comprise capital provided by foreign investors, directly or indirectly to enterprises in another economy with an expectation of obtaining better profits and also participation in the management of the enterprise in which they invest. The foreign investors acquire ownership of assets in the host

Revised Manuscript Received on September 25, 2019

* Correspondence Author

Dr. A. MUTHUSAMY, Professor, Department of International Business, Alagappa University, Karaikudi, Tamilnadu, India..

G.KALPANA, Research Scholar, Department of Commerce, Alagappa University, Karaikudi, Tamilnadu, India. country firms in proportion to their equity holdings. The Government of India is also making sincere efforts to attract and promote foreign direct investment to supplement domestic capital, technology, and skill, for accelerated economic growth. Foreign direct investment, as distinguished from portfolio investment, has the connotation of establishing a 'lasting interest' in an enterprise that is resident in an economy other than that of the investor.

Foreign investment can reduce the domestic savings-investment gap. Hence, notwithstanding the domestic savings-investment gap, economic growth can be increased in an open economy with the inflow of foreign investment. Foreign investment in India would stimulate domestic investments. Foreign investments are complementary to economic growth and development in developing countries like India. Investment in an economy raises output and improves the standard of livings of the people. Keeping this end in view both developed and developing countries are trying their best to undertake investment program. Since the availability of capital is scarce in many countries due to the low rate of domestic savings, the importance of foreign investment is ever rising. The multinational corporation is a suitable device to integrate the world economy. The growth of foreign investment is directly associated with the growth of multinational corporations.

\section{CIVIL AVIATION}

The Civil Aviation sector includes Airports, Scheduled and Non-Scheduled domestic passenger airlines, Helicopter services/Seaplane Services, Ground Handling Services, Maintenance, and Repair organizations; Flying training institutes, and Technical training institutions. For the purposes of the Civil Aviation sector: Scheduled air transport service is an air transport service undertaken between the same two or more places and operated according to a published time table or with flights so regular or frequent that they constitute a recognizably systematic series, each flight being open to using by members of the public. Non-Scheduled air transport service" means any service which is not a scheduled air transport service and will include Cargo airlines; Cargo airlines 


\section{The Influence of FDI with GDP its Impact of FDI in Civil Aviation Sector in India}

such airlines which meet the conditions as given in the Civil Aviation Requirements issued by the Ministry of Civil Aviation. Ground Handling" means ramp handling, traffic handling both of which shall include the activities as specified by the Ministry of Civil Aviation through the Aeronautical Information Circulars from time to time, and any other activity specified by the Central Government to be a part of either ramp handling or traffic handling

\section{Airports}

Airports activity under the FDI conditions, the first one is Greenfield projects is 100 percent of (FDI) Equity Cap and route entry is automatic. The second activity is existing projects here also ca of (FDI) Equity is 100 percentage, the route entry is automatic up to $74 \%$ beyond the government route $74 \%$.

\section{Air transport service}

The scheduled air transport service or domestic scheduled passenger airlines 49 percentage of equity FDI, 100 percentages for NRIs and entry route is automatic. The non-scheduled air transport service has cap 74 $\%$ for FDI, 100 for NRIs, the entry route is automatic up to $49 \%$, and entry route is automatic up to $49 \%$ the government route beyond $49 \%$ and up to $74 \%$.

\section{Gross Domestic Product}

GDP is the market value of final goods and services. If a country enjoys a large GDP by depleting its natural capital, GDP can be used by governments as a strategic weapon in a world where nations compete against one another for economic and political influence. Not only does a nation's status in the world increase if it enjoys GDP growth, but high GDP also enables a nation to gradient the terms of trade with the rest of the world to its advantage. Indian economic growth was very slow even after independence because it depended on agriculture. The government of India initiated some reform measures aimed at increasing domestic competitiveness in the 1980s. The recognition that the controls and subsidies introduced by the Congress governments during the earlier phase were not serving their intended purpose had gradually dawned on the establishment during the late seventies. The new government gradually initiated a new approach to economic management. During the '80s there was a shift towards the ascendancy of services relative to the industry in growth. The rising share of the public sector was the main source of an increasing share of services in GDP.

\section{IMPORTANCE OF THE STUDY}

FDI is a very important role in the development of country economics. Most countries followed to liberalize and promote foreign investment to encourage growth in the last ten years. FDI provides a condition wherein both mass and home country gets the benefits. FDI provides financial resources, capital, entrepreneurship, and managerial skills and whereas to the home country, it provides an enormous market. FDI provides a stable inflow of funds, access to international markets, export growth, transfer of technology skills and improves the balance of payments. The Civil Aviation Sector includes Airports, Scheduled and Non-Scheduled, Domestic Passenger Airlines Helicopter Services, Ground Handling Services, Maintenance and Repair Organizations, Flying Training Institutes and Technical Training Institutions. The government has issued the National Civil Aviation Policy on 2016. The Civil Aviation Sector currently contributes $\$ 72$ billion to Gross Domestic Product. The National Civil Aviation Policy covers the policy areas such as Regional Connectivity, Safety, Air Transport Operation, 5/20 requirement for International Operations, Bilateral Traffic Rights, Fiscal Support, Maintenance, Repair and Overhaul, Air Cargo, Aeronautical 'Make In India'. The Central Government announces that the foreign airlines now will be allowed to invest domestic airlines up to 49 percent.

\section{REVIEW OF LITERATURE}

(Veena Tewari Nandi, 2013) in her study remained an exception globally, to the process of economic liberalization. The global airline industry remains the subject to several restrictions in terms of operations and its ownership with control. The most of the countries impose restriction in this one sector, because that benefits national entries and debar foreign investors generally for security reason in the common practice a majority of the countries is both in the development and the developing world. (Chalapati Rao \& Biswajit Dhar, 2018) in their study expressed the need to review India's FDI policy which, being largely aimed at attracting investment, has failed to retain investment and harness technology to

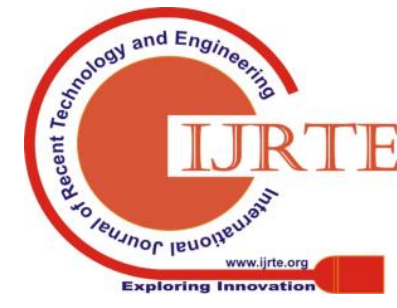


the extent possible. Building on the experience of the previous research at the institute, it hopes that this study will convince the Indian authorizes and caution the users nationally and internationally about the pitfalls in offering simplistic explanations for the reported developments and that it would help develop a template to analyze the inflows purposefully. (Syed Azhar \& Marimuthu K.N 2012) in their study attempted to make an analysis of FDI in India and its impact on growth. it also focuses on the determinants and needs of FDI, year-wise analysis, sectoral analysis and sources of FDI and reasons. One of the economic aspects of globalization is the fact that increasing investments in the form of foreign direct investments. In recent times due to the global recession, most of the countries have not been able to pull investments. Better FDI's than the developed countries even during the crisis period also. Especially in recent years, the FDI in India has been following a positive growth rate.

\section{HYPOTHESIS OF THE STUDY}

The following hypotheses were framed for analyzing the data $\mathrm{H}_{01}$ : There is no significant relationship between Gross Domestic Product and FDI Inflows, Aviation Sector Equity Inflows

$\mathrm{H}_{02}$ : There is no significant influence between Gross Domestic Product and FDI Inflows, Aviation Sector Equity Inflows

\section{METHODOLOGY}

The study is based on empirical and the data available in the reserve bank of India statistical report was accomplished. The secondary data was used for the research study enormously. FDI and GDP data were collected from World Bank data, RBI annual reports from its websites.

\section{PERIOD OF THE STUDY}

The period was 10 years taken from 2009-10 to 2018-19.

\section{DATA ANALYSIS}

The following table highlights the FDI Inflows and GDP during the period from 2009-10 to 2018-19.

Table 1: FDI Inflows in India during the year from 2009-10 to $2018-19$

\begin{tabular}{|c|c|c|c|}
\hline Year & $\begin{array}{c}\text { FDI Inflows } \\
\text { (Amount in } \\
\text { Millions US } \\
\text { \$) }\end{array}$ & $\begin{array}{c}\text { Growth } \\
\text { Rate \% }\end{array}$ & $\begin{array}{c}\text { GDP } \\
\text { (Amount in } \\
\text { Millions US \$) }\end{array}$ \\
\hline $2009-10$ & 25834 & -- & 7861882.3 \\
\hline $2010-11$ & 21383 & -17.22 & 8497586.8 \\
\hline $2011-12$ & 35121 & 64.24 & 5241314.2 \\
\hline $2012-13$ & 22423 & -36.15 & 5456387.5 \\
\hline $2013-14$ & 24299 & 8.36 & 6386106.4 \\
\hline
\end{tabular}

\begin{tabular}{|c|c|c|c|}
\hline $2014-15$ & 29737 & 22.37 & 7410227.6 \\
\hline $2015-16$ & 40001 & 34.51 & 7996253.7 \\
\hline $2016-17$ & 43478 & 8.69 & 8169526.5 \\
\hline $2017-18$ & 44857 & 3.17 & 7167888.8 \\
\hline $2018-19$ & 44366 & -1.09 & 6982333.5 \\
\hline Total & $\mathbf{3 3 1 4 9 9}$ & & $\mathbf{7 1 1 6 9 5 0 7 . 3}$ \\
\hline Mean & $\mathbf{3 3 1 4 9 . 9 0}$ & & $\mathbf{7 1 1 6 9 5 0 . 7 3 0 0}$ \\
\hline SD & $\mathbf{9 5 2 9 . 9 7 9 4 5}$ & & $\mathbf{1 1 1 8 4 5 6 . 8 9 0 4 8}$ \\
\hline
\end{tabular}

Source: Computed from RBI, World Bank data.

The above table the Foreign Direct Investment in India during the study period from 2009-10 to 2018-19 has been shown in table 1 and present figure 1 . The FDI which was merely 25834 Million US\$ in 2009-10 it was increased to 44366 Million US\$ in 2018-19. There has been wide variation in FDI Inflow in India. The government of India has been continuously liberalizing the FDI policy to attract high foreign investment in the country. In the initial year 2009-10, the flow of FDI inflow was relatively high merely volume with to 25834 Million US\$ in 2009-10 to 21383Million US\$ in 2010-11. There has been downward movement in FDI Inflow 21383Million US \$ in the year 2010-11. There has been an upward movement of FDI Inflow 35121 Million US\$ in 2011-12. The followed the year 2012-13 the FDI Inflows was decreased 22423 Million US\$. The next two following years 2013-14 and 2014-15 was a slight variation of FDI Inflows in India. In the followed the year 2015-16 the FDI Inflow was relatively high volume with 40001Million US\$. In the followed the year 2016-17 the FDI Inflows is million US\$ 43478, there has been wide variation from previous years. The followed next two years continuously growth in FDI inflows in India. The GDP also year- by- year continuously increased.

Figure 1

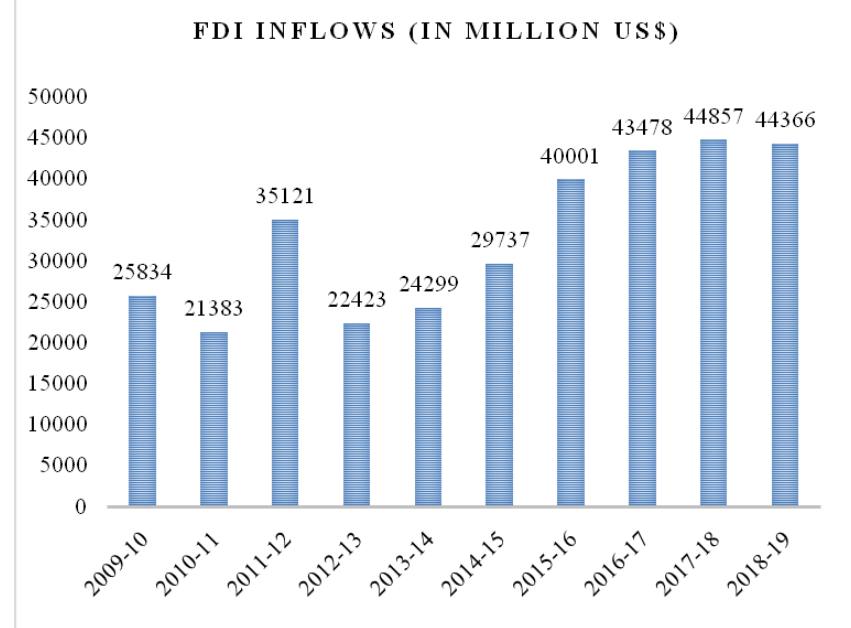

The flow of FDI in India has been showing the rising trend despite year-wise is fluctuations. The gross total inflow of FDI increased at an annual exponential compound growth rate every year is quite high. 


\section{REGION-WISE FDI INFLOWS IN INDIA}

The following tables the highlights of Region -Wise FDI Inflows in India during the year from October 2014 to March 2018. The region-wise FDI inflow has been given table 2 .

Table 2: Region-wise FDI Inflows in India (October 2014March 2018)

\begin{tabular}{|c|c|c|c|}
\hline S.No & $\begin{array}{l}\text { Region offices } \\
\text { of RBI }\end{array}$ & $\begin{array}{l}\text { Amount of } \\
\text { FDI Inflows }\end{array}$ & $\begin{array}{l}\text { FDI Inflows in } \\
\text { Percentage }\end{array}$ \\
\hline 1. & Mumbai & 46152.37 & 31.92 \\
\hline 2. & New Delhi & 30731.76 & 21.26 \\
\hline 3. & Bangalore & 17710.52 & 12.25 \\
\hline 4. & Chennai & 12047.43 & 8.33 \\
\hline 5. & Ahmedabad & 8655.95 & 5.99 \\
\hline 6. & Hyderabad & 5576.53 & 3.86 \\
\hline 7. & Kolkata & 1363.19 & 0.94 \\
\hline 8. & Kochi & 936.95 & 0.65 \\
\hline 9. & Jaipur & 348.43 & 0.24 \\
\hline 10. & Kanpur & 252.1 & 0.17 \\
\hline 11. & Bhopal & 184.41 & 0.13 \\
\hline 12. & Panaji & 169.81 & 0.12 \\
\hline 13. & Chandigarh & 145.91 & 0.1 \\
\hline 14. & $\begin{array}{l}\text { Bhubaneshwa } \\
\mathrm{r}\end{array}$ & 83.64 & 0.06 \\
\hline 15. & Patna & 65.9 & 0.05 \\
\hline 16. & Guwahati & 28.4 & 0.02 \\
\hline 17. & Jammu & 1.93 & 0 \\
\hline 18. & $\begin{array}{l}\text { Region Not } \\
\text { Indicated }\end{array}$ & 20119.89 & 13.92 \\
\hline & Grand Total & 144575.13 & --- \\
\hline
\end{tabular}

Source: Computed from Ministry of Commerce/Department for Promotion of Industry and Internal Trade

The above table 2 the Region -Wise FDI inflows in India. The country is divided into a different region based on the RBI regional offices. Accordingly, India is divided into 18 regions Mumbai and Delhi received about one and half of the total FDI in India from October 2014 to March 2018. Mumbai region topped with FDI Inflow of US\$ 46152.37 million and accounted for 31.92 percent of total FDI in India. Delhi region with FDI Inflow of US\$30731.76 million has been in the next place and accounted for 21.26 percent of total FDI in India. The other important regions in the descending order are Bangalore, Chennai, Ahmedabad, Hyderabad, Kolkata, Kochi, Jaipur, Kanpur, Bhopal, Panaji, Chandigarh, Bhubaneshwar, Patna, Guwahati, Jammu, and Regions Not Indicated. It's clear from the study of the region-wise breakup of FDI Inflows in India. It has been mainly concentrated in economically well-advanced regions.
These regions have developed infrastructure and other facilities to foreign investors.

Figure 2

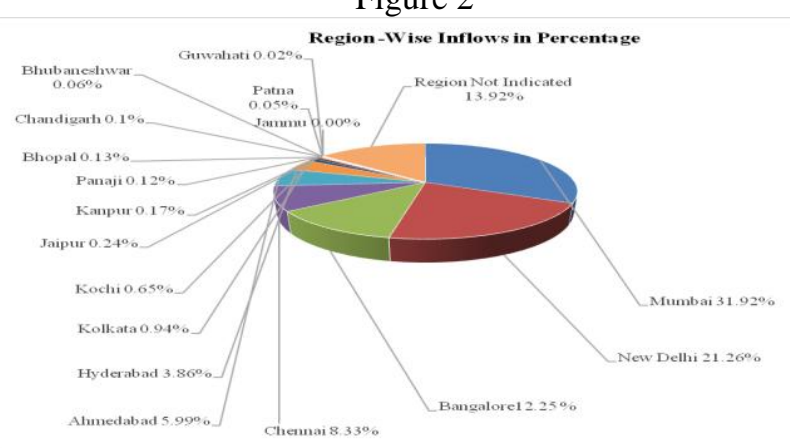

Table 3: FDI equity Inflows in Aviation Sector

\begin{tabular}{|c|c|c|c|}
\hline Year & $\begin{array}{c}\text { FDI Inflows } \\
\text { (In Million } \\
\text { US\$) }\end{array}$ & $\begin{array}{l}\text { Growth } \\
\text { Rate } \%\end{array}$ & $\begin{array}{l}\text { Trend } \\
\text { Value }\end{array}$ \\
\hline 2009-10 & 4391.93 & --- & \\
\hline $2010-11$ & 3403.08 & -17.22 & \\
\hline 2011-12 & 5215.98 & 64.24 & \\
\hline $2012-13$ & 4832.98 & -36.15 & \\
\hline 2013-14 & 2225.10 & 8.36 & \\
\hline 2014-15 & 3250.03 & 22.37 & \\
\hline $2015-16$ & 6889.46 & 34.51 & \\
\hline 2016-17 & 8684.07 & 8.69 & \\
\hline 2017-18 & 6708.58 & 3.17 & \\
\hline 2018-19 & 9157.54 & -1.09 & \\
\hline Total & 49925.77 & & \\
\hline Mean & 5475.87 & & \\
\hline SD & 2329.50 & & \\
\hline 2019-20 & & & 8494.669 \\
\hline 2020-21 & & & 9413.134 \\
\hline 2021-22 & & & 10161.78 \\
\hline 2022-23 & & & 11292.65 \\
\hline 2023-24 & & & 12444.01 \\
\hline
\end{tabular}

Source: Computed from the Department for Promotion of Industry and Internal Trade

\section{CORRELATION ANALYSIS}

Ho: There is no significant relationship between Gross Domestic Product and FDI Inflows, Aviation Sector Equity Inflows

Table 4:Correlation Analysis

\begin{tabular}{|c|c|c|c|c|}
\hline \multicolumn{2}{|c|}{ Particular } & GDP & FDI & $\begin{array}{c}\text { Aviation } \\
\text { Sector- } \\
\text { Equity } \\
\text { Inflow } \\
\end{array}$ \\
\hline \multirow[t]{2}{*}{ GDP } & \begin{tabular}{|l|} 
Pearson \\
Correlation \\
\end{tabular} & 1 & & \\
\hline & $\begin{array}{l}\text { Sig. } \\
\text { (2-tailed) }\end{array}$ & & & \\
\hline FDI & $\begin{array}{l}\text { Pearson } \\
\text { Correlation }\end{array}$ & .145 & 1 & \\
\hline
\end{tabular}




\begin{tabular}{|l|l|c|c|c|}
\hline & $\begin{array}{l}\text { Sig. } \\
(2 \text {-tailed })\end{array}$ & .690 & & \\
\hline $\begin{array}{l}\text { Aviation } \\
\text { Sector-Equit } \\
\text { y Inflow }\end{array}$ & $\begin{array}{l}\text { Pearson } \\
\text { Correlation }\end{array}$ & .162 & $.869^{* *}$ & 1 \\
\cline { 2 - 5 } & $\begin{array}{l}\text { Sig. } \\
(2-\text { tailed })\end{array}$ & .655 & .001 & \\
\hline
\end{tabular}

** Correlation is significant at the 0.01 level (2-tailed).

The above table 4represents the correlation coefficient of FDI Inflows, Aviation Sector Equity Inflows, and GDP. It is observed that the GDP is insignificant and positively correlated with FDI. Aviation Sector equity inflow is significant and positively correlated with FDI. Aviation sector equity inflow is insignificant and positively correlated with GDP.

\section{REGRESSION ANALYSIS}

Ho: There is no significant influence between Gross Domestic Product and FDI Inflows, Aviation Sector Equity Inflows

Table 5:Regression Analysis

\begin{tabular}{|c|c|c|c|c|c|c|}
\hline \multirow{2}{*}{\multicolumn{2}{|c|}{ Model }} & \multicolumn{3}{|c|}{ Unstandardized Coefficients } & \multirow[b]{2}{*}{$\mathbf{t}$} & \multirow[b]{2}{*}{ Sig. } \\
\hline & & & & Std.Error & & \\
\hline \multicolumn{2}{|l|}{ (Constant) } & \multicolumn{2}{|c|}{6665680.912} & 1607161.186 & 4.147 & .004 \\
\hline \multicolumn{2}{|l|}{ FDI Inflows } & \multicolumn{2}{|c|}{1.877} & 88.448 & .021 & .984 \\
\hline \multicolumn{2}{|c|}{ Aviation Sector-Equity Inflows } & \multicolumn{2}{|c|}{71.050} & 361.840 & .196 & .850 \\
\hline \multicolumn{6}{|l|}{$\mathrm{R}$} & $.162^{\mathrm{a}}$ \\
\hline \multicolumn{6}{|l|}{ R Square } & .026 \\
\hline \multicolumn{6}{|c|}{ Adjusted R Square } & -.252 \\
\hline \multicolumn{6}{|l|}{$\mathrm{F}$} & .094 \\
\hline \multicolumn{6}{|c|}{ Durbin- Waston } & 1.396 \\
\hline \multicolumn{7}{|c|}{ ANOVA } \\
\hline Model & \multicolumn{2}{|c|}{ Sum of Squares } & Df & Mean Square & $\mathbf{F}$ & Sig. \\
\hline Regression & \multicolumn{2}{|c|}{295721087312.061} & 2 & 147860543656.030 & .094 & $.911^{\mathrm{b}}$ \\
\hline Residual & \multicolumn{2}{|c|}{10962791255354.380} & 7 & 1566113036479.197 & & \\
\hline Total & \multicolumn{2}{|c|}{11258512342666.441} & 9 & & & \\
\hline
\end{tabular}

Source: Computed from SPSS version 23.

It implies that with the rise of US\$ 1 in FDI Inflow, there will be an increase of 1.87 and 71.050 in the GDP. From the table 5, it is observed that multiple regression coefficients (R) between the Gross Domestic Product and the independent variables are taken together with the value of $R 0.162, R$ Square 0.026 , which means 2.60 percentage of the variation is explained by the regression analysis. Adjusted R Square -0.252 indicates the coefficient of determination which is negatively associated in the regression equation. The value of $F$ is 0.094 which examines that the $F$ value is less than the table value of all the variables collectively of the regression function. Durbin - Waston statistic informs us whether the assumption independent error is reasonable. It concludes that GDP is significantly influenced by its independent variables.

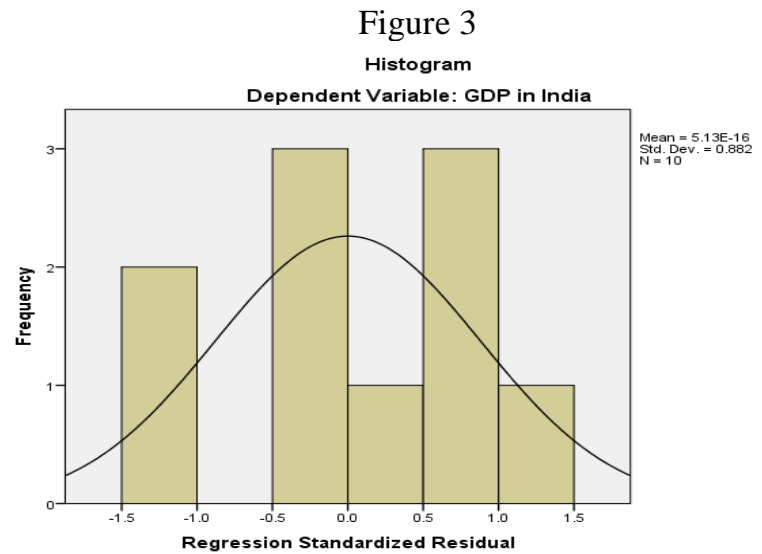

Published By: 


\section{The Influence of FDI with GDP its Impact of FDI in Civil Aviation Sector in India}

Figure 4

Normal P-P Plot of Regression Standardized Residual Dependent Variable: GDP in India

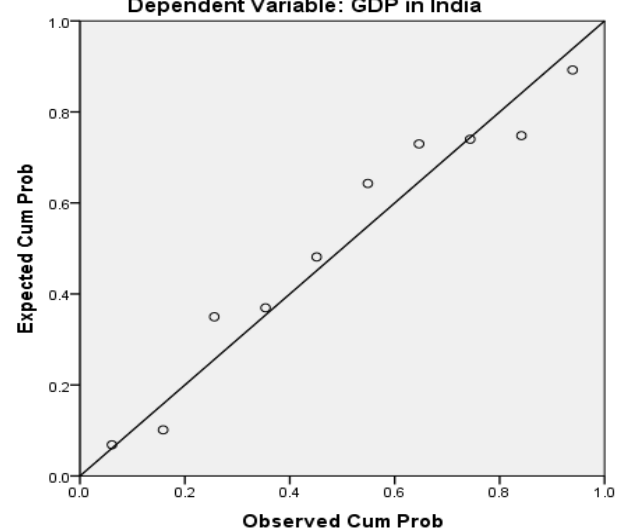

Figure 5

Scatterplot

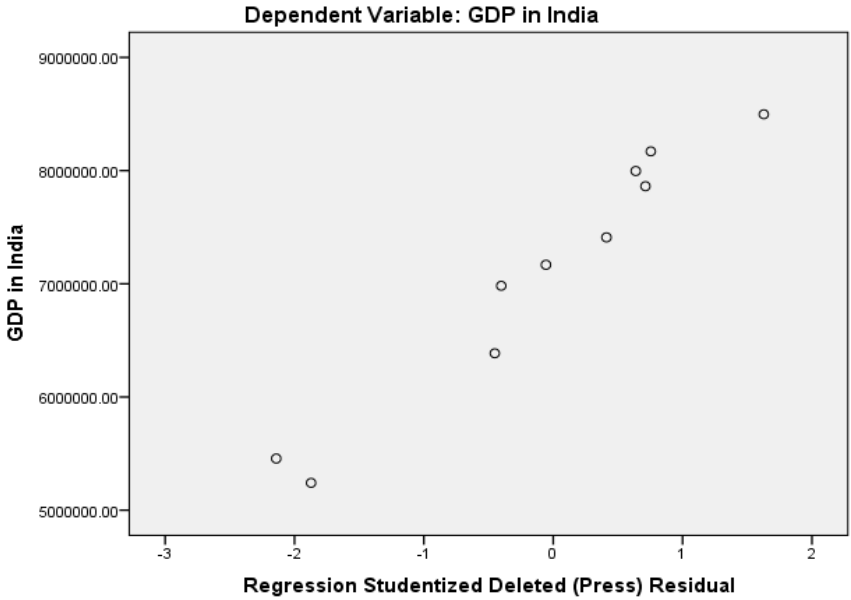

X. CONCLUSION

FDI has become the noise word across the globe, every country need to optimize its resources and would like to increase its share in the world trade and would want to fare well on account of the indices which would ensure that its economy's trajectory is on the right track, in order to attract foreign investment and expertise to meet its target. The researcher concludes the positive impact of FDI in Aviation Sector. There is the plentiful scope of FDI inflow to Indian in the future. There is a significant relationship between Gross Domestic Product and FDI Inflows, Aviation Sector Equity Inflows and there is significant influence between Gross Domestic Product and FDI Inflows, Aviation Sector Equity Inflows.

\section{ACKNOWLEDGEMENT}

I hearty thank to the department of International Business in Alagappa University. This research work was partially supported and sponsored by RUSA 2.0 scheme of MHRD in Alagappa University, Karaikudi.

\section{REFERENCES}

[1] Veena Tewari Nandi, (2013) FDI in Aviation: Retrospection in the Indian Economy, Business and Information 2013, Bali, July 7-9

[2] Syed Azhar \& K.N. Marimuthu, (2018), An overview of Foreign Direct Investment in India, International Journal of Multidisciplinary management studies, Vol, 2, Issue 1, January 2012, ISSN: 22498834
[3] Anil Duggal, (2017), Foreign Direct Investment in India, Journal of Internet Banking and Commerce, December 2017, Vol: 22, No: 3.

[4] Computed from Department for Promotion of Industry and Internal Trade: Date: July 2019

[5] The World Bank Data, Date: July 2019 